\title{
ENERGI PENYIMPANAN \\ PADA PABRIK PENGGILINGAN PADI KAPASITAS KECIL
}

\author{
Indriyani $^{1)}$, Ari Beni Santoso ${ }^{2)}$ \\ 1),2) Dosen Tetap Yayasan pada Program Studi Teknik Mesin Fakultas Teknik \\ Universitas Sang Bumi Ruwa Jurai \\ Email korespondensi: indryinthan@gmail.com dan indriyani@saburai.ac.id
}

\begin{abstract}
Abstrak
Aspek penanganan pascapanen sampai pada proses penyimpanan perlu diperhatikan secara serius dalam upaya peningkatan produksi, karena kondisi iklim terutama pada saat musim hujan akan sangat berpengaruh terhadap hasil pengeringan gabah, baik menyangkut rendemen maupun kualitas gabah. Pengembangan teknologi penyimpanan harus terus dilakukan, untuk tetap menjaga kualitas beras yang sudah dikemas. Metode yang digunakan adalah dengan metode survei langsung ke Pabrik Penggilingan Padi Kapasitas Kecil. Pemilihan lokasi pada penelitian ini dilakukan secara sengaja (purposive) Energi penyimpann PPP-KK lebih efisien bahkan persentase beban operasionalnya mencapai 127,99 \% karena PPP-KK menggunakan energi terkecil. Rerata energi penyimpanan PPPKK 10,45 kJ/kg dan rerata efisiensi energi peyimpanan PPP-KK 224,69 kJ/kg. Analisis rerata efisiensi energi penyimpanan yang didapatkan pada PPP-KK, karena pengoperasionalannya lebih banyak menggunakan energi manusia dengan kapasitas beban operasional lebih besar dari kapasitas beban maksimum.
\end{abstract}

Kata kunci: Energi Penyimpanan, Pabrik Penggilingan Padi Kapasitas Kecil, Energi Manusia, Energi Motor, Kapasitas Beban Maksimum

\begin{abstract}
The aspect of post-harvest handling to the storage process needed to be taken seriously in efforts to increase production, because climatic conditions, especially during the rainy seasons would greatly affect the yield of grain drying both regarding the yield and quality of grain. The development of storage technology must be continued, to maintain the quality of the packaged rice. The method used was the direct survey method to the Small Capacity Rice Mill (SC-RMF). The location selection in this study was carried out purposively. The energy storage of SC-RMF was more efficient, even the percentage of operational load reached 127,99\% because SC-RMF used the smallest energy. The average SCR-MF storage energy was $10,45 \mathrm{~kJ} / \mathrm{kg}$ and the average SC-RMF storage energy efficiency was $224,69 \mathrm{~kJ} / \mathrm{kg}$. Analysis of the average energy efficiency obtained in SC-RMF because its operation used more human energy with an operational load capacity greater than the maximum load capacity.
\end{abstract}

Keywords: Energy Storage, Small Capacity Rice Milling Factory (SC-RMF), Human Energy, Motor Energy, Maximum Load Capacity

\section{PENDAHULUAN}

Energi penyimpanan pada Pabrik Penggilingan Padi Kapasitas Kecil (PPP -KK) perlu ditingkatkan dalam upaya untuk menjaga kualitas beras yang telah dikemas. Pabrik Penggilingan Padi (PPP) pada tahun 2010 telah mencapai 108.512 unit dengan kapasitas kumulatif diperkirakan 109,5 juta ton per tahun (Patiwiri, 2006). Produksi padi nasional hanya 60,3 juta ton, setara dengan 39,2 juta ton beras dengan faktor konversi dari gabah ke beras $65 \%$. 
Hal ini menyebabkan banyak unit penggilingan padi bekerja di bawah kapasitas terpasang. Gejala ini sebenarnya telah terjadi sejak tahun 2003, diperkirakan hanya $40 \%$ unit penggilingan padi yang beroperasi dengan kapasitas penuh (Thahir, 2010).

Aspek penanganan pascapanen sampai pada proses penyimpanan perlu diperhatikan secara serius dalam upaya peningkatan produksi, karena kondisi iklim terutama pada saat musim hujan akan sangat berpengaruh terhadap hasil pengeringan gabah, baik menyangkut rendemen maupun kualitas gabah. Pengembangan teknologi penyimpanan harus terus dilakukan, untuk tetap menjaga kualitas beras yang sudah dikemas.

Di Provinsi Lampung, khususnya di Kabupaten Pesawaran dan Kabupaten Pringsewu banyak ditemukan Pabrik Penggilingan Padi (PPP) dengan berbagai kapasitas: kecil, menengah dan besar. Energi penyimpanan masih menggunakan energi manusia dalam proses penyimpanan ke gudang. Energi manusia PPP-KK masih dihargai dengan jasa yang murah (bersifat utama). Pengoperasionalan PPP belum memanfaatkan optimalisasi energi penyimpanan sesuai dengan spesifikasi standar. Resiko energi penyimpanan yang tidak efisien selalu terjadi, dan hal ini perlu diatasi di masa yang datang.

Berdasarkan jumlah mesin dan kemampuan harian menggiling padi, unit penggilingan padi digolongkan atas Pabrik Penggilingan Padi Kapasitas Besar (PPP-KB) lebih besar dari 2,00 ton/jam, Pabrik Penggilingan Padi Kapasitas Menengah (PPP-KM) 1,00 - 1,99 ton/jam, Pabrik Penggilingan Padi Kapasitas Kecil (PPP-KK) 0,60 - 0,99 ton/jam, dan Pabrik Penggilingan Padi Keliling (PPP-KL) lebih kecil 0,60 ton/jam beras giling. Pengolahan produk samping, mulai dari pemanfaatan menir menjadi tepung komposit, bekatul, dan sekam (Thahir, 2010).

Tenaga manusia merupakan sumber energi yang tidak dapat dipisahkan pada setiap kegiatan proses penggilingan padi. Energi yang diukur pada manusia bervariasi karena pada dasarnya nilai energi tersebut berasal dari kandungan energi makanan yang dikonsumsi dan kapasitas ventilasi jantung dan paru - paru. Kapasitas seseorang melakukan kerja produktif berbeda - beda, tergantung dari sifat-sifat tubuh manusia untuk merubah bentuk energi, tingkat konsumsi makanan, jenis pekerjaan, lama pekerjaan dan keadaan lingkungan. Sedangkan sifat tubuh manusia yang berpengaruh adalah tinggi, berat, kekuatan tulang dan otot, umur dan keterampilan.

Orang yang berumur 50 tahun memiliki kapasitas energi $80 \%$ dari umur 25 tahun, sedangkan orang yang berumur 60 tahun memiliki kapasitas energi sebesar $60 \%$ dari umur 25 tahun. Klasifikasi beban kerja pada tenaga manusia berumur 20 - 50 tahun untuk melakukan aktifitas pada beberapa kondisi beban kerja. Setiap tahap proses berhubungan dengan manusia, baik sebagai pengendali maupun sebagai tenaga kerja langsung. Besarnya tenaga manusia yang dibutuhkan pada operasional PPP dapat dihitung.

Berdasarkan atas pengujian dengan menggunakan parameter - parameter tersebut dibuat tabel, untuk menentukan tingkat kerja yang dilakukan seperti yang tertera pada tabel 1 . 
Tabel 1. Tingkat kerja fisik yang diukur berdasarkan tingkat penggunaan energinya (untuk pria dewasa sehat)

\begin{tabular}{llcccc}
\hline No. & \multicolumn{1}{c}{$\begin{array}{c}\text { Tingkat } \\
\text { kerja }\end{array}$} & $\begin{array}{c}\text { Konsumsi } \\
\text { energi dalam } 8 \\
\text { jam (kkal) }\end{array}$ & $\begin{array}{c}\text { Konsumsi } \\
\text { energi } \\
\text { (kkal/menit) }\end{array}$ & $\begin{array}{c}\text { Konsumsi } \\
\text { oksigen } \\
\text { (l/menit) }\end{array}$ & $\begin{array}{c}\text { Denyut jantung per } \\
\text { menit }\end{array}$ \\
\hline 1. & Istirahat & 720,0 & 1,5 & 0,3 & $60,0-70,0$ \\
2. & Sangat ringan & $768,0-1.200,0$ & $1,6-2,5$ & $0,3-0,5$ & $65,0-75,0$ \\
3. & Ringan & $1.200,0-2.400,0$ & $2,5-5,0$ & $0,5-1,0$ & $75,0-100,0$ \\
4. & Sedang & $2.400,0-3.600,0$ & $5,0-7,5$ & $1,0-1,5$ & $100,0-125,0$ \\
5. & Berat & $3.600,0-4.800,0$ & $7,5-10,0$ & $1,5-2,0$ & $125,0-150,0$ \\
6. & Sangat berat & $4.800,0-6.000,0$ & $10,0-12,5$ & $2,0-2,5$ & $150,0-180,0$ \\
7. & Luar biasa Berat & $6.000,0$ & 12,5 & 2,5 & 180,0 \\
\hline
\end{tabular}

Sumber: American Industrial Hygiene Association (2010)

\section{METODOLOGI PENELITIAN}

Metode yang digunakan adalah dengan metode survei langsung ke Pabrik Penggilingan Padi Kapasitas Kecil. Pemilihan lokasi ini dilakukan secara sengaja (purposive) yaitu di Kabupaten Pesawaran dan Kabupaten Pringsewu, dengan pertimbangan bahwa banyak terdapat Pabrik Penggilingan Padi berdasarkan data yang didapat dari Kantor BULOG Drive V Provinsi Lampung.

Bahan yang digunakan dalam penelitian ini adalah padi. Alat yang digunakan adalah stateskop meter (pengukur denyut jantung), motor, mobil, kalkulator, satu set komputer/laptop, dan software Microsoft Excel 2010. Data primer didapatkan melalui survei energi penyimpan pada Pabrik Penggilingan Padi Kapasitas Kecil. Data sekunder didapatkan melalui Kantor BULOG Drive V Provinsi Lampung, Jurnal Ilmiah, dan Buku Referensi lainnya.

\section{Energi Manusia (Ems)}

Energi manusia $\left(E_{\mathrm{mns}}\right): \quad \frac{\mathrm{E}_{\mathrm{rke}}}{\mathrm{t}_{\mathrm{std}}} \frac{\mathrm{t}_{\mathrm{bki}}}{\mathrm{m}_{\mathrm{pdi}}} \mathrm{k}_{\mathrm{mns}}$

Caranya:

1. Mencatat usia seseorang (tahun), jarak tempuh $(\mathrm{km})$, kapasitas beban mengangkut padi (kg/hari), waktu bekerja (jam/hari).

2. Menghitung denyut jantung setelah, seseorang baru saja selesai mengangkut padi dengan menggunakan stateskop meter.

3. Setelah diukur denyut jantung seseorang ditentukan tingkat kerja, dan konsumsi energi dalam 8 jam (kkal/kg) dapat dilihat pada Tabel 2.

4. Menghitung energi seseorang sebagai berikut:

\section{Energi Motor $\left(\mathbf{E}_{\mathbf{m t r}}\right)$}

Energi motor $\left(E_{\mathrm{mtr}}\right): \frac{\mathrm{E}_{\text {bensin }} l_{\text {bensin }}}{\mathrm{m}_{\mathrm{pdi}}}$

Caranya: 
1. Mencatat jenis motor, tahun produksi pabrik, kecepatan $(\mathrm{km})$, jarak tempuh $(\mathrm{km})$, kapasitas beban mengangkut padi (kg/hari), kebutuhan bahan bakar (liter/jam), waktu bekerja (jam/hari), dan nilai kalor bensin 32,24 (mJ/liter) dapat dilihat pada Tabel 1.

2. Menghitung energi motor (Emtr) sebagai berikut:

$$
\frac{\text { Ebensin }_{\text {bensin }}}{\mathrm{m}_{\text {pdi }}}
$$

Keterangan:

Emtr : Energi motor

$E_{\text {bensin }} \quad$ : Nilai kalor bahan bakar bensin $(32,24 \mathrm{~mJ} /$ liter terdapat pada Tabel 1)

$l_{\text {bensin }} \quad$ : Kebutuhan bahan bakar bensin (liter/jam)

$\mathrm{m}_{\mathrm{pdi}} \quad$ : Kapasitas beban padi yang diangkut $(\mathrm{kg} / \mathrm{hari})$

\section{Energi Mesin Penyimpan ( $\left.\mathbf{E}_{\mathrm{mpy}}\right)$}

Energi mesin penyimpan $\left(\mathrm{E}_{\mathrm{mpy}}\right)$ : $\frac{\mathrm{E}_{\text {listrik }} 1_{\text {solar }}}{\mathrm{m}_{\text {brs }}}$

Caranya:

1. Mencatat merk mesin pengemas, tahun produksi pabrik, lama pemakaian (tahun), kapasitas beban (kg/hari), kebutuhan bahan bakar solar (liter/jam), waktu bekerja (jam/hari), dan nilai kalor listrik (38,66 mJ/liter) pada Tabel 1.

2. Menghitung energi mesin penyimpan $\left(\mathrm{E}_{\mathrm{mpy}}\right)$ sebagai berikut:

Keterangan:

Emp : Energi mesin penyimpan

$\mathrm{y}$

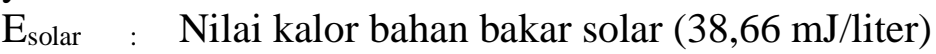

$1_{\text {solar }} \quad$ : Kebutuhan bahan bakar solar (liter)

$\mathrm{m}_{\text {brs }} \quad$ : Kapasitas beban beras yang disimpan $(\mathrm{kg})$

\section{HASIL DAN PEMBAHASAN}

Energi penyimpanan yang dimaksud dalam penelitian ini adalah penyimpanan beras yang telah dikemas dengan karung plastik $10 \mathrm{~kg}, 25 \mathrm{~kg}$ dan $50 \mathrm{~kg}$ ke tempat penyimpanan yang telah beralaskan papan dengan sirkulasi udara yang baik, sehingga beras yang telah dikemas tidak mudah busuk dalam jangka waktu maksimal 2 bulan.

Rerata energi penyimpanan PPP-KK terdapat $10,45 \mathrm{~kJ} / \mathrm{kg}$ dengan rerata kapasitas beban $1.721,05 \mathrm{~kg} / \mathrm{hari}$ yang terdiri dari: energi manusia (handling) $10,45 \mathrm{~kJ} / \mathrm{kg}$ dengan rerata kapasitas beban $1.721,05 \mathrm{~kg} / \mathrm{hari}$, dan tidak ditemukan energi mesin penyimpanan dapat dilihat pada Tabel 2. 
Tabel 2. Rerata Energi Penyimpanan PPP-KK

\begin{tabular}{llrr}
\hline No. & Jenis sub energi & \multicolumn{1}{l}{$\begin{array}{c}\text { Rerata } \\
\text { beban } \\
\text { (kg/hari) }\end{array}$} & $\begin{array}{r}\text { Rerata } \\
\text { energi } \\
\text { (kJ/kg) }\end{array}$ \\
\hline $1 . \quad$ Energi manusia (handling) & $1.721,05$ & 10,45 \\
\hline $2 . \quad$ Energi mesin penyimpan & 0,00 & 0,00 \\
\hline Rerata & $\mathbf{1 . 7 2 1 , 0 5}$ & $\mathbf{1 0 , 4 5}$ \\
\hline
\end{tabular}

Sumber Data: Pengolahan Data

Efisiensi energi pada PPPKK dikarenakan rerata energi penyimpanan PPPKK $(10,45$ $\mathrm{kJ} / \mathrm{kg}$ ) yang terdiri dari: energi manusia (handling) $(10,45 \mathrm{~kJ} / \mathrm{kg}$ ), dan tidak ditemukan energi mesin penyimpanan dapat dilihat pada Tabel 2. Hal ini disebabkan energi manusia lebih banyak digunakan pada proses penyimpanan beras yang telah dikemas ke tempat penyimpanan.

\section{KESIMPULAN}

Berdasarkan perhitungan pada energi penyimpann PPP-KK lebih efisien bahkan persentase beban operasionalnya mencapai 127,99 \% karena PPP-KK menggunakan energi terkecil. Rerata energi penyimpanan PPPKK $10,45 \mathrm{~kJ} / \mathrm{kg}$ dan rerata efisiensi energi peyimpanan PPP-KK 224,69 kJ/kg. Analisis rerata efisiensi energi penyimpanan yang didapatkan pada PPPKK, karena pengoperasionalannya lebih banyak menggunakan energi manusia dengan kapasitas beban operasional lebih besar dari kapasitas beban maksimum.

\section{DAFTAR PUSTAKA}

Abdullah, K. (2010). Energi dan Listrik Pertanian. JICA-DGHE/IPB Project/ ADAET. IPB. Bogor.

Adang K. (2010). Analisis Beban Kerja Operator Mesin Polisher ICHI pada Proses Penggilingan Padi Berdasarkan Recommended Weight Limit (RWL) Sebagai Upaya Peningkatan Produktivitas dan Keselamatan Kerja, Orasi Ilmiah, Jurusan Teknik dan Manajemen Industri, Fakultas Teknik, Universitas Pasundan Bandung.

Chamsing, A., V.M. Salokhe, dan G. Singh. (2010). Energy Comsumption Analysis for Selected Crops in Different Regions of Thailand. Agricultural Engineering International: CIGR Ejournal, Volume VIII page 120.

Cervinka, V. (2010). Fuel and Energy Efficiency dalam Handbooks of Energy Utilization in Agricultural. Pimentel, D. CRC. Press, Inc. Boca Raton, Florida. USA.

Fluck, R.C. (2010). Energy in Florida Agriculture, downloadable matter, http://edis.ifas.ufl.edu/EH/EH 17900.pdf. Diakses pada tanggal 24 Mei 2012. 
Lembaga Ilmu Pengetahuan Indonesia (LIPI), 2010. Menggantikan Solar, Sekam Bisa Diubah jadi Sumber PLTD, http://www.energi.lipi.go.id. Media Indonesia (1 September 2003). Diakses pada tanggal 20 Mei 2012.

Setyono A. (2010). Perbaikan Teknologi Pascapanen Dalam Upaya Menekan Kehilangan Hasil Padi. Jurnal Pengembangan Inovasi Pertanian Balai Besar Penelitian Tanaman Padi. Subang.

Singh, H., D. Mishra, dan N.M. Nahar. (2002). Energy Use Pattern in Production Agriculture of Typical Village in Arid Zone India - Part I. Energy. Convers. Manag.

Thahir R. (2010). Revitalisari Penggilingan Padi Melalui Innovasi Penyosohan, Mendukung Swasembada Beras dan Menghadapi Persaingan Global, Badan Penelitian dan Pengembangan Pertanian, Orasi Pengukuhan Profesor Riset Bidang Teknologi Pengolahan Hasil (Teknologi Pascapanen) Departemen Pertanian. IPB. Bogor. 